\title{
Melanotic Neuroectodermal Tumor
}

National Cancer Institute

\section{Source}

National Cancer Institute. Melanotic Neuroectodermal Tumor. NCI Thesaurus. Code C3717.

A rare neoplasm usually occurring in infants. It is characterized by the presence of a mixture of melanin-containing epithelial cells and smaller neuroblast-like cells. It may involve the skull and facial bones, or the epididymis. It usually has a benign clinical course. 